\title{
ALKALOSIS IN THE VOMITING OF INFANCY
}

\author{
BY \\ MONTAGUE MAIZELS, M.D., M.R.C.P., \\ Pathologist to the Infants' Hospital, Westminster, London.
}

Alkalosis and reduction of blood chlorides are known to occur in some cases of pyloric stenosis in infants (Hartmann and Smythe ${ }^{1}$, Graham and Morris ${ }^{2}$, Maizels, McArthur and Payne $^{3}$ ). The present investigation endeavours to determine how far such changes are characteristic of this malady. To this end, the chemical and clinical findings in consecutive cases occurring at the Infants' Hospital have been analysed and compared with the findings in other forms of vomiting. Certain forms of vomiting have been excluded : namely, vomiting in infants over three months old ; vomiting accompanied by diarrhœa, and vomiting cases which had received alkalis medicinally.

Conditions investigated.-The cases investigated are classified as follows :

Group 1. Vomiting due to obstruction of the alimentary canal ; under three months, this is practically equivalent to pyloric stenosis or pylorospasm.

Group 2. Habit vomiting and vomiting due to unsuitable feeding. These cases being neither obstructive, nor toxic, nor infective, have been grouped together for convenience.

Group 3. Toxic or infective vomiting. The number of examples in this group is small, because although toxic and infective vomiting is common, it is rarely unaccompanied by diarrhoa.

The following cases have been classed as pyloric stenosis :

(a) Cases where the diagnosis has been confirmed at operation or post mortem (79 per cent. of all cases).

(b) Cases not so confirmed, but presenting typical signs, including tumour (16 per cent.).

(c) Cases where no tumour had been felt, but wasting, projectile vomiting, constipation and visible peristalsis were present, and marked gastric delay was shewn radiographically. There were four examples in the present sories, three of which may have been cases of spasm rather than stenosis.

Some of the clinical findings in obstructive and non-obstructive cases are summarized in Table 1.

It will be seen that there is no clinical feature apart from pyloric tumour, which may not occur in non-obstructive conditions. Thus positive radio- 
graphic findings and some degree of visible peristalsis have been observed in several cases of Group 2. In Group 1, on the other hand, radiography was negative in three cases, and inconclusive in eleven others where the diagnosis was subsequently confirmed. In six of these fourteen cases, the stools were practically normal, indicating that the pyloric obstruction was only partial. In two of these cases with normal stools, the pylorus could not be felt and a diagnosis of simple pyloric spasm was made. Both these cases died of enteritis. At autopsy, in each case, the pyloric muscle was found to be four millimetres thick, but the canal admitted a five millimetre rod.

TABLE 1.

Clinical details in Groups 1 and 2.

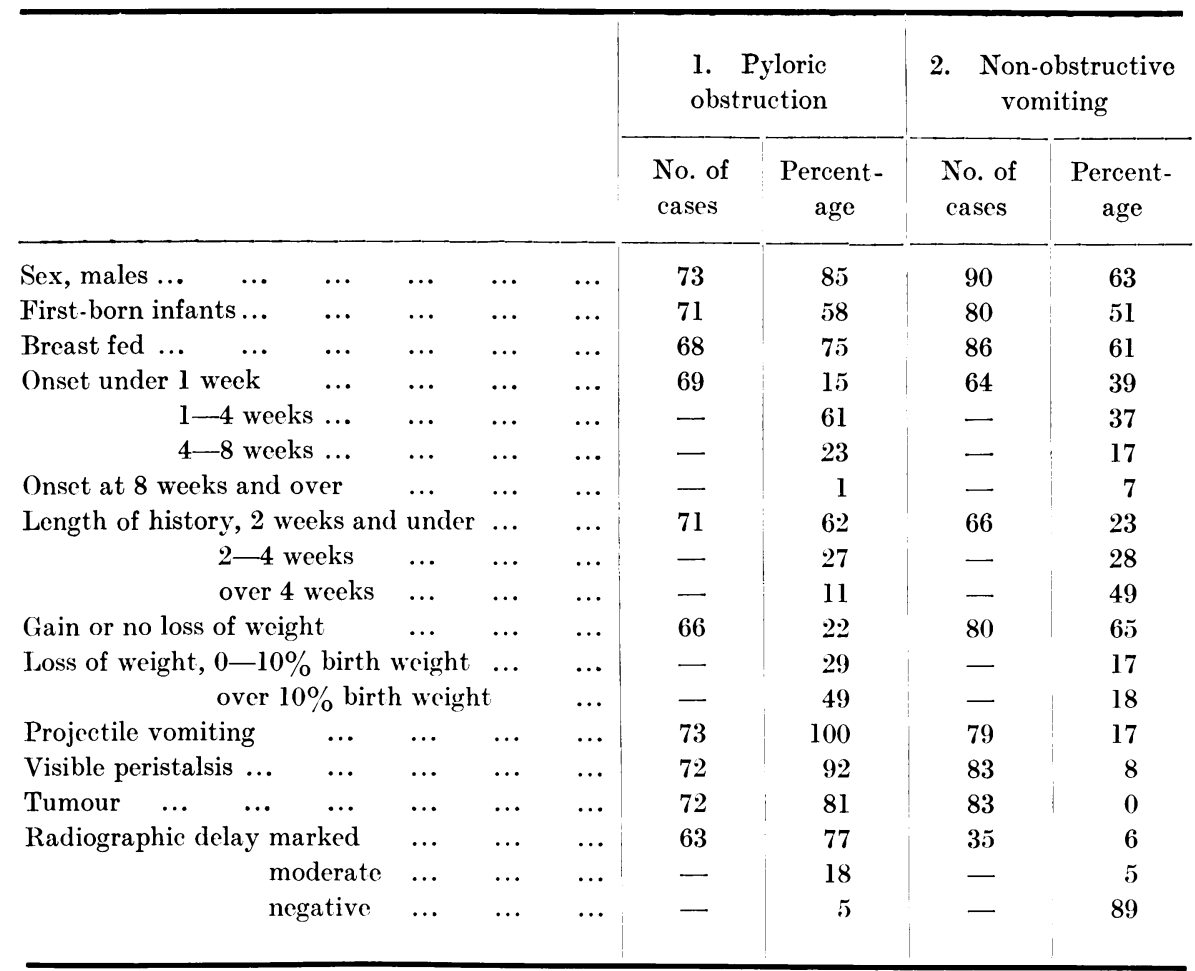

There were two pairs of brothers in Group 1. Three cases in this group vomited blood before operation.

The mortality in Group 1, was 18 per cent. Four cases were practically moribund on admission, and seven died of enteritis. The mortality among the surgical cases was 8 per cent. (4 of 50 cases) and was due to enteritis.

Chemical findings in cases of persistent vomiting.- The following have been investigated: Plasma bicarbonate, plasma and red cell chloride, the ratio of cell to plasma chloride (R), and the hæmoglobin.

The normal plasma bicarbonate lies between 22 and 28 millimoles; the plasma chloride between 95 and 105, and the cell chloride between 44 and 56 
millimoles, and $\mathrm{R}$ varies between $0 \cdot 44$ and $0 \cdot 56$. These figures may be compared with the findings in vomiting infants (Table 2).

REsults.-Group 1. In the blood of pyloric obstruction, four divergencies from the normal were common : increase of the plasma bicarbonate (78 per cent. of cases), decrease of the plasma chloride ( 67 per cent.), decrease of red cell chloride (88 per cent.), and increase of the hæmoglobin. In some cases, however, these changes were absent, or present singly, or together, or in various combinations. Irrespective of the other chemical changes the hæmoglobin was sometimes increased as a result of loss of fluid from the body.

TABLE 2.

Analysis of the BloOD IN CASES OF PERSistent vomiting.

\begin{tabular}{|c|c|c|c|c|c|}
\hline \multirow{2}{*}{ Analysis } & \multirow{2}{*}{ Range } & \multicolumn{2}{|c|}{ Group 1} & \multicolumn{2}{|c|}{ Group 2} \\
\hline & & $\begin{array}{l}\text { No. of } \\
\text { cases }\end{array}$ & $\begin{array}{l}\text { Percent- } \\
\text { age }\end{array}$ & $\begin{array}{l}\text { No. of } \\
\text { cases }\end{array}$ & $\begin{array}{l}\text { Percent- } \\
\text { age }\end{array}$ \\
\hline Plasma bicarbonate .. & $\begin{array}{l}\text { Under } 22 \mathrm{mM} \text {. } \\
22-28 \quad, \\
28-(34),, \\
34-(40),, \\
40 \text { and over }\end{array}$ & 73 & $\begin{array}{l}1 \cdot 5 \\
20 \cdot 5 \\
22 \\
27 \\
29\end{array}$ & 47 & $\begin{array}{r}15 \\
79 \\
6 \\
0 \\
0\end{array}$ \\
\hline Plasma chloride & $\begin{array}{l}\text { Over } 105 \mathrm{mM} . \\
95-105 \quad, \\
90-(95) \quad, \\
75-(90) \quad, \\
\text { Under } 75 \quad,\end{array}$ & 74 & $\begin{array}{l}5 \cdot 5 \\
27 \\
17 \cdot 5 \\
39 \\
11\end{array}$ & 47 & $\begin{array}{r}28 \\
66 \\
6 \\
0 \\
0\end{array}$ \\
\hline Cell chloride $\quad \ldots \quad \ldots$ & $\begin{array}{l}\text { Over } 45 \mathrm{mM} . \\
(40)-44, \\
33-40, \\
\text { Under } 33,\end{array}$ & 73 & $\begin{array}{l}12 \\
14 \\
46 \\
28\end{array}$ & 47 & $\begin{array}{r}62 \\
35 \\
3 \\
0\end{array}$ \\
\hline $\begin{array}{l}\text { Ratio of cell to plasma } \\
\text { chloride }(R) \ldots\end{array}$ & $\begin{array}{l}0.44 \text { and over } \\
\text { Between } 0.4 \text { and } 0.44 \\
0.33-0.4 \\
\text { Under } 0.33\end{array}$ & 73 & $\begin{array}{r}34 \\
22 \\
37 \\
7\end{array}$ & 47 & $\begin{array}{r}57 \\
30 \\
13 \\
0\end{array}$ \\
\hline
\end{tabular}

The lowest chloride values occurred in cases with the severest alkalosis. When the alkali reserve was normal, or only slightly raised, the plasma chloride was sometimes only slightly diminished, but in eight instances, the reduction of plasma and especially of cell chloride was considerable, although the plasma bicarbonate was normal (Table 3, Cases 15, 57 and 62).

The various chemical changes were not proportionate to the length of history, and seemed to depend more on the severity of the symptoms than on their duration.

Icterus was present in four patients on admission. The indirect van den Bergh test alone was positive and the urine contained no bile. The hæmo- 
globin content of the blood was high in all these cases. One of these patients was under three weeks old, and one was a premature infant. Within two weeks, the jaundice had disappeared.

The urine in pyloric stenosis never contained more than a trace of chloride. While absence of chloride from the urine is frequent in all forms of vomiting,

TABLE 3.

Chemical changes Resulting from vomiting.

\begin{tabular}{|c|c|c|c|c|c|c|c|c|c|c|c|}
\hline 号 & 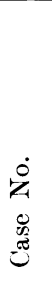 & $\begin{array}{l}\widehat{T} \\
\frac{\pi}{8} \\
0 \\
0 \\
0 \\
0 \\
\frac{0}{4}\end{array}$ & 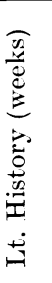 & 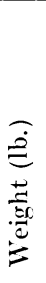 & 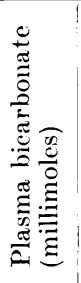 & 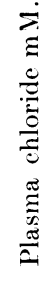 & 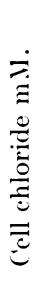 & 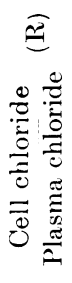 & 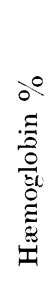 & 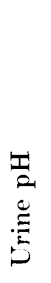 & 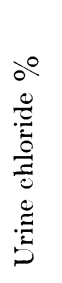 \\
\hline \multirow[t]{16}{*}{1} & 11 & 8 & - & $4 \frac{3}{4}$ & $34 \cdot 7$ & 108 & 48 & 0.45 & 48 & $6 \cdot 5$ & 0 \\
\hline & 15 & 6 & 3 & 8 & 24 & 98 & 35 & $0 \cdot 36$ & 100 & $7 \cdot 2$ & 0 \\
\hline & 19 & 10 & 10 & $9 \frac{1}{2}$ & $44 \cdot 4$ & 80 & 28 & $0 \cdot 35$ & 85 & $7 \cdot 7$ & 0 \\
\hline & 22 & 3 & 1 & 7 & $28 \cdot 5$ & 105 & 51 & $0 \cdot 49$ & 110 & $5 \cdot 8$ & 0.03 \\
\hline & 31 & 7 & 5 & 6 & 57 & 68 & 24 & $0 \cdot 36$ & 85 & $7 \cdot 2$ & 0 \\
\hline & 34 & 2 & 1 & $7 \frac{1}{2}$ & 40 & 76 & 32 & 0.42 & 117 & $6 \cdot 5$ & 0 \\
\hline & 39 & 9 & 3 & $7 \frac{1}{2}$ & $35 \cdot 5$ & 94 & 46 & 0.49 & - & $7 \cdot 6$ & 0 \\
\hline & 41 & 4 & 4 & $5 \frac{1}{2}$ & $53 \cdot 1$ & 57 & 28 & $0 \cdot 49$ & 91 & - & - \\
\hline & 44 & 4 & 2 & $7 \frac{1}{4}$ & $30 \cdot 5$ & 77 & 27 & 0.35 & 67 & - & - \\
\hline & 48 & 7 & 2 & 6 & $55 \cdot 4$ & 54 & 21 & $0 \cdot 38$ & 一 & $7 \cdot 2$ & 0 \\
\hline & 57 & 5 & 1 & $8 \frac{1}{4}$ & $27 \cdot 4$ & 79 & 34 & $0 \cdot 43$ & - & - & - \\
\hline & 59 & 5 & 2 & $7 \frac{1}{4}$ & $35 \cdot 2$ & 75 & 23 & $0 \cdot 30$ & 104 & $7 \cdot 2$ & 0 \\
\hline & 60 & 4 & $\frac{1}{2}$ & 7 & $27 \cdot 8$ & 99 & 46 & $0 \cdot 46$ & 76 & - & - \\
\hline & 62 & 7 & 1 & 4 & $26 \cdot 6$ & 87 & 27 & $0 \cdot 31$ & 136 & 6 & 0 \\
\hline & 63 & 3 & 1 & 6 & $36 \cdot 5$ & 92 & 32 & 0.35 & 121 & 6 & 0 \\
\hline & 70 & 5 & 1 & $4 \frac{1}{4}$ & $40 \cdot 2$ & 101 & 43 & 0.42 & 82 & - & - \\
\hline \multirow[t]{7}{*}{2} & 2 & 12 & 10 & 8 & $25 \cdot 3$ & 99 & 46 & $0 \cdot 47$ & 70 & $6 \cdot 6$ & 0 \\
\hline & 9 & 8 & 6 & $7 \frac{3}{4}$ & $18 \cdot 1$ & 103 & 51 & 0.52 & 91 & $5 \cdot 7$ & 0.06 \\
\hline & 17 & 7 & 7 & $5 \frac{1}{2}$ & $33 \cdot 3$ & 101 & 42 & 0.41 & 97 & - & - \\
\hline & 24 & 6 & 2 & $8 \frac{3}{4}$ & $33 \cdot 5$ & 101 & 43 & 0.43 & - & - & - \\
\hline & 37 & 8 & 8 & 6 & $26 \cdot 6$ & 99 & 46 & 0.46 & 67 & $7 \cdot 3$ & 0 \\
\hline & 38 & 4 & 4 & $6 \frac{1}{4}$ & $27 \cdot 4$ & 105 & 46 & 0.44 & 133 & $7 \cdot 5$ & $0 \cdot 18$ \\
\hline & 39 & 9 & 3 & 8 & $25 \cdot 2$ & 102 & 35 & $0 \cdot 34$ & 77 & $7 \cdot 2$ & 0 \\
\hline \multirow[t]{3}{*}{3} & 1 & 6 & - & 7 & $22 \cdot 2$ & 106 & 53 & $0 \cdot 50$ & - & $5 \cdot 2$ & 0.06 \\
\hline & 7 & 5 & - & - & $6 \cdot 5$ & 132 & 71 & $0 \cdot 54$ & 100 & - & - \\
\hline & 9 & 12 & 2 & $4 \frac{3}{4}$ & $29 \cdot 6$ & 117 & 48 & $0 \cdot 41$ & 68 & - & - \\
\hline
\end{tabular}

and does not necessarily indicate pyloric stenosis, the presence of more than 0.07 per cent. makes obstruction very improbable. When alkalosis was present, the urine was usually alkaline (72 per cent.), but in some cases, the urine was acid in spite of alkalosis.

Diacetic acid was never found in the urine. A moderate amount of acetone was found in 10 per cent. of cases, and traces in a further 9 per cent. 
The gastric residue was examined in ten cases. It contained chloride $(0 \cdot 1$ to $0 \cdot 27$ per cent.) and was acid. In one case the $\mathrm{pH}$ was $2 \cdot 2$, in another, $2 \cdot 4$; in the remaining eight, it lay between 3 and $4 \cdot 5$. It is probable thot at leest part of the acidity in all these casas was due to hydrochloric acid.

Examples of the various blood changes likely to occur in pyloric obstruction sre shewn in Table 3.

After the therapeutic administration of normal saline and glucose (15 to $20 \mathrm{oz}$. over a period of 48 hours), as a rule, the alkali resørve decreased, the plasma and red cell chloride, and the ratio of cell to plasma chloride ( $\mathrm{R})$ rose, while the hæmoglobin and hæmatocrite reading fell owing to retention of water in the circulation. In many cases, the fall in the hæmatocrite reading was much less marked than the fall in hæmoglobin, indicating that relatively more water was retained in the red cell than in the plasma. In one third of the cases, all the changes resulting from treatment were present simultaneously. In the other cases one or more of these changes were absent. The aikali reserve shewed a marked fall in 56 per cent. of cases and this fall was accompanied by a corresponding rise in the chloride.

TABLE 4.

1)IagNostic Value of Chemical aNalyses.

\begin{tabular}{lllllllc}
\hline \multicolumn{1}{c}{ Analysis } & \multicolumn{1}{c}{ Group 1 } & Group 2 \\
\hline 1. Plasma bicarbonate $34 \mathrm{mM}$. or more & $\ldots$ & $\ldots$ & $\ldots$ & $\ldots$ & $56 \%$ & $0 \%$ \\
2. Plasma chloride under $90 \mathrm{mM}$. & $\ldots$ & $\ldots$ & $\ldots$ & $\ldots$ & $\ldots$ & $50 \%$ & $0 \%$ \\
3. Cell chloride, $40 \mathrm{~m} . \mathrm{M}$. or less & $\ldots$ & $\ldots$ & $\ldots$ & $\ldots$ & $\ldots$ & $74 \%$ & $3 \%$ \\
1,2 and 3 all positive together & $\ldots$ & $\ldots$ & $\ldots$ & $\ldots$ & $\ldots$ & $38 \%$ & $0 \%$ \\
1,2 or 3 positive separately, i.e., total positives $\ldots$ & $\ldots$ & $\ldots$ & $88 \%$ & $3 \%$ \\
\hline
\end{tabular}

In the majority of surgical cases, the blood had become normal or neiriy normal within ten days of the operation.

In the cases of Group 2 (habit vomiting and vomiting due to incorrect feeding) alkalosis was very rare, although minor degrees of chloride reduction were not uncommon. Examples are shewn in Table 3.

There were only ten cases of toxic and infective vomiting without diarrhoa Group 3. In these, the bicarbonate was normal or low, and the chloride normal or high (Table 3).

Summary.-It is considered that any of the following findings taken by itself is almost diagnostic of obstructive as opposed to non-obstructive vomiting :-

1. Plasma bicarbonate 34 millimoles or more.

2. Plasma chloride less than 90 millimoles.

3. Red cell chloride 40 millimoles or less.

Exceptions to this rule are occasionally afforded by certain cases of diarrhoea.

Table 4 has been constructed on the basis of these figures. The data have been collected from the very first chemical examinations made on patients after entering the hospital; usually within a few hours of admission. 
Significance of the chemical alterations in the blood.-In pyloric obstruction, quite apart from clinical and radiographic evidence, chemical investigation gives characteristic findings in 88 per cent. of cases at the first examination. It is necessary to consider how far a diagnosis may be based on such findings.

Reduction of plasma chloride and increase of the alkali reserve are found in conditions where hydrochloric acid is lost in the vomit or excess of sodium chloride is lost from the body by any route,- vomit, stools, urine or sweat.

The infrequency of marked chemical changes in the vomiting of infants resulting from incorrect feeding or toxæmia indicates that the loss of $\mathrm{HCl}$ and $\mathrm{NaCl}$ in these conditions must, as a rule, be slight ; in the former, it is probable that the vomit contains but little gastric secretion, while in the latter, there is evidence that infection leads to a secretion deficient in acids and salts.

In vomiting accompanied by diarrhœa, acidosis is commonly present and the blood chlorides are increased; sometimes, however, the alkali reserve remains normal or may even shew a slight increase, and the chlorides may be low, normal or high. When the alkali reserve is normal or raised, and the chlorides diminished, the blood changes are identical with those of pyloric obstruction. For this reason, cases of vomiting with diarrhœea, have not been included for comparison with other forms of vomiting.

The blood chemistry in intestinal obstruction may be normal, or it may resemble that of pyloric stenosis. In the present series is a case of duodenal stenosis which shewed dehydration, normal plasma bicarbonate and low plasma and cell chloride.

It is not possible to distinguish pyloric stenosis from simple pylorospasm by chemical tests alone. The diagnosis of spasm is not always clearly defined. It may be presumed that projectile vomiting, visible peristalsis and delay in emptying are characteristic ; a tumour is not felt and the stools contain more fæcal material than is the case in stenosis. It is probable that the majority of such cases are really varieties of stenosis in which the obstruction is partial, intermittent or of short duration. Example of pure pylorospasm must be rare, for in the present series, 95 per cent. of cases were outspoken stenosis.

Alkalosis and reductions of blood chlorides may also occur when alkalis have been given therapeutically. In such circumstances, if the kidneys are not functioning normally, the urine may be acid and chloride free. But if renal function is maintained, the urine will be alkaline and contain a large excess of chloride. In this type of case, the cause of the alkalosis should be evident.

It appears, therefore, that alkalosis and low blood chlorides in an infant of under three months, who vomits but has no diarrhœea, indicates a diagnosis of pyloric obstruction,--stenosis or spasm. Negative chemical findings, however, do not exclude obstruction. It may be doubted, perhaps, if additional aids to diagnosis are required. As a rule, the diagnosis of stenosis is straightforward, but sometimes cases occur with atypical symptoms, and in such as these chemical examination has been of assistance.

Chemical examination is of less value in assessing the severity of a case than in its diagnosis for cases with normal or nearly normal blood findings 
are not always mild, and may be in urgent need of treatment. On the other hand, patients with severe alkalosis and marked diminution of chlorides may respond readily to medical treatment, in which case, the bicarbonate will begin to decrease, and the chloride to increase. Failure of this to occur in a few days, or persistence of dehydration as shewn by a high and rising hæmoglobin value, are indications that medical treatment is not likely to be successful. If such a case had originally been regarded as one of spasm, it is probable that the diagnosis should be revised.

The chemical findings also show the importance of copious saline infusions in the treatment of these patients, while the high hæmoglobin values indicate that the actual transfusion of blood is not often needed.

Blood analysis is sometimes of service in diagnosing the cause of relapse in improving surgical and medical cases. In such circumstances, the infant looks pale and toxic; the weight falls and vomiting may recur. Marked alkalosis and low plasma chloride may be found. Such cases are liable to sudden collapse, but will probably improve with normal salines. But if any degree of acidosis has supervened an infection has occurred and the outlook is not good. Enteritis or otitis may be present (10 per cent. of cases in this series).

It is probable that the chemical findings in pyloric stenosis arise from loss of hydrochloric acid, sodium chloride and water in the vomit; the variations in the components of the blood depending on the relative proportions of these substances wasted in the gastric juice.

There are, theoretically, several possibilities :

1. Water loss, through vomiting, exceeds the loss of chloride (i.e., the vomit contains relatively little chloride). This is exceptional in uncomplicated cases, but occurs with the supervention of enteritis or otitis. It leads to dehydration, lactic acid formation in the tissues and phosphate retention by the kidneys. It results in acidosis and a relative or absolute increase in the blood chlorides.

2. Water and total chloride loss are proportional, and the vomit is only slightly acid, containing $\mathrm{NaCl}$, and but little $\mathrm{HCl}$. Dehydration occurs, but otherwise the blood remains nearly normal (Table 3, Case 22.)

3. Water and total chloride loss are proportional, but the vomit is moderately acid containing both $\mathrm{NaCl}$ and $\mathrm{HCl}$; alkalosis with normal plasma chloride results (Table 3, Cases 11 and 70.)

4. Chloride loss is relatively greater than water loss and the vomit is acid. Dehydration with alkalosis and reduction of plasma chloride occur (Table 3, Cases 19, 31, 41, 48 and 59.)

5. Chloride loss is relatively greater than water loss, but the vomit is only slightly acid (that is, the vomit contains $\mathrm{NaCl}$ but little $\mathrm{HCl}$ ). The plasma chloride will necessarily diminish, and the bicarbonate may remain normal (Table 3, Cases 15, 44, 57, 62), or it may increase. This increase of plasma bicarbonate through loss of $\mathrm{NaCl}$ alone, without loss of significant quantities of $\mathrm{HCl}$, is explained by Hartmann and $\mathrm{Smyth}^{1}$ in the following 
manner: loss of $\mathrm{NaCl}$ from the blood brought about by any means, lowers the osmotic pressure of the plasma. The maintenance of the osmotic pressure of the plasma is of the first importance, and is brought about by the nonexcretion on the part of the kidney of any substance that can be retained in the blood. This includes substances like chloride and urea. It does not include non-threshold substances like sulphuric and phosphoric acids, but it does include the fixed base, with which these substances are excreted in the urine of the normal individual. On account of the deficiency of available chlorine in the blood, the fixed base so retained is neutralized, not with chlorine but with carbon-dioxide, and the base bicarbonate of the plasma is increased. By this means the osmotic pressure of the plasma is maintained, while the reaction of the blood is kept relatively constant by underbreathing and the retention of corresponding amounts of $\mathrm{CO}_{2}$. Owing to the necessity for this base retention, the acids excreted in the urine are combined with the minimum amount of base, and in spite of the alkalosis the urine remains acid. Further, the basic radicle with which the urinary acids are combined, is not fixed base, but ammonia.

Hence, if Hartmann and Smyth's explanation is correct, one would expect cases of this type, with low plasma chloride, to have a high plasma bicarbonate and urea, and to excrete an acid urine, relatively free from fixed base, and with a high ammonia coefficient: a urine, in effect, resembling that excreted in acidosis.

Previous work (Maizels, McArthur and Payne ${ }^{3}$ ) has led to the inference, that the connexion between osmotic pressure and blood urea, is not very close, and this has been supported by subsequent observations.

The relation of the osmotic pressure to the reaction of the urine must bc discussed at greater length. The osmotic pressure of the plasma can be determined from the depression of the freezing point, or indirectly if the concentration of its various constituents are known. Hartmann and Darrow ${ }^{4}$ have shewn that sodium chloride, base-bicarbonate, protein, phosphate, lactate, glucose and urea, together account for 93 per cent. of the observed osmotic pressure. In the present investigation, the data are not complete, for in several cases, only the $\mathrm{HCO}_{3}$ and $\mathrm{Cl}$ are known. In the normal infant, these account for about 250 osmolar millimoles, while the other constituents provide about 40. In pyloric stenosis, this residue of phosphorus, urea, lactate and protein, is either normal or increased. If, therefore, in those cases where the bicarbonate and chloride values are alone available, the residue is assumed to be normal, the results obtained will indicate the least probable osmotic pressure of the plasma examined. The Appendix (page 302) has been constructed on the basis of Hartmann and Darrow's figures and the osmotic pressures calculated in Cases 42, 58, 63, 74 and 75 are minimal. In Cases 48,49 and 59, the data are complete, except for the concentration of lactate. In these three cases, the osmotic pressure would still be less than normal, even if the lactate were' increased.

If the foregoing assumptions are allowed, the following observotions may be made. Alkaline urines were much commoner than acid urines, and while 
most of these urines were associated with alkalosis and a plasma osmotic nressure which was normal or even high, in five cases, it is probable that the osmotic pressure was low (s a Appendix, Cases 48, 49 and 59). As for the cases with acid urines and alkalosis, in some of these (five cases) the osmotic pressure, so far from being low, was normal or increased (sae Appendix, Cases 42,58 and 63 ). In the others (three cases) it is likely that the osmotic pressure was less than normal (Appendix, 74 and 75), but even in these three cases, as in the preceding five, it can be shewn from the titratable acidity and ammonia of the urine, and also from the urinary chloride, phosphate and sulphate, that the acid radicles are combined with a high proportion of fixed bases and that the ammonia coefficient is not raised. The findings are therefore, the reverse of what might be expected from Hartmann and Smyth's explanation. It seems likely that the excretion of an acid urine in the presence of alkalosis depends on some cause besides variations in the osmotic pressure of the blood ; possibly on toxæmia or dehydration with renal damage and imperfect ammonia formation by the kidney.

Graham and Morris ${ }^{2}$ remark that the magnitude of blood changes is by no means proportional to the degree of vomiting, and recount a case where alkalosis was present in the absence of vomiting. They hold therefore that other factors must be considered besides loss of chloride in the gastric juice. In one case only of the present series, alkalosis increased long after the vomiting had ceased. Here, however, aspiration of gastric residue and levage were carried out, and in this way, about three ounces of fluid were removed daily, a loss which might gradually have produced the alkalosis. In such cases as this, treated with prolonged lavage, it might be wise to complete the procedure by leaving a few ounces of normal saline in the stomach.

The absence of chloride from the urine in pyloric stenosis is due to the fall of blood chloride. It is true that in two cases, No. 11 and 22, the plasma chloride was raised, but in both of these dehydration was present, so that the total chloride in circulation was low. Under such circumstances, the renal threshold might conceivably be raised.

\section{Conclusions.}

1. Alkalosis or marked reduction of chloride is rare in non-obstructive vomiting.

2. In pyloric obstruction, there is frequently a marked increase of the plasma bicarbonate and decrease of the plasma and chloride cell. One or more of these changes are present in 88 per cent. of all cases and have a positive diagnostic significance.

3. Negative chemical findings do not exclude pyloric obstruction.

Thanks are due to the medical staff of the Infants' Hospital for permission to publish accounts of their cases and to Miss C. B. McArthur who has carried out some of these investigations, and in collaboration with whom, certain observations have already been published; also to the British Medical Association for a grant for the purchase of apparatus. 
Methods. - Most of the methods employed have been described in a previous communication (Maizels and McArthur ${ }^{5}$ ). Phenol-phthalein was the indicator used in titrating the urines. The method of estimating plasma bicarbonate is that of Payne ${ }^{3}$. The determination of base was carried out by the method of Stadie and Ross ${ }^{6}$. The validity of the cell chloride estimation is discussed elsewhere?

\section{APPENDIX.}

Plasma osmotic pressure and the reaction of the URine in cases of alkalosis.

Normal Infant. (Hartmann and Darrow).-Plasma : $\mathrm{NaCl}, 200$. $\mathrm{HCO}_{3}, 48 \cdot 7$. Protein, 15·6. Phosphate (P) 5·5. Lactate, 4·2. Glucose, 6·4. Urea, 8. Total, 288 osmolar millimoles.

Case 42.-Plasma : $\mathrm{NaCl}, 178$. $\mathrm{HCO}_{3}$, 74. P, 9.1. Urea, 11. Unestimated residue, 26.2. Minimum osmotic pressure, 298. Urine: pH. 5.2. Acidity, 98 milliequivalents. $\mathrm{NH}_{3}, 62$. Cl, 0. $\mathrm{P}_{2} \mathrm{O}_{5}, 54$. $\quad \mathrm{NH}_{3}$ coeff., $13 \cdot 3 \%$. Traces of albumin and acetone.

Case 48.-Plasma : $\mathrm{NaCl}, 108 . \mathrm{HCO}_{3}, 113$. Protein, 16.7. P, 9.2. Glucose, 8·3. Urea, 17. Residue, 4.2. Osmotic pressure, 276. Urine: pH. 7.4. $\mathrm{Cl}, 0$.

Case 49.-Plasma : $\mathrm{NaCl}, 134 . \mathrm{HCO}_{3}, 90$. Protein, 16.7. P, 3.7. Glucose, 6.3. Urea, 16. Residue, 4.2. Total, 271. Urine : $\mathrm{pH} .7 \cdot 8$.

Case 58.-Plasma : $\mathrm{NaCl}, 188$. $\mathrm{HCO}_{3}, 65 \cdot 5$. Residue, 40 at least. Minimum O.P., 293. Urine : pH. 6. Acidity, 92. $\mathrm{NH}_{3}, 21 . \mathrm{Cl}, 0 . \mathrm{SO}_{4}, 40 . \mathrm{P}_{2} \mathrm{O}_{5}, 81 . \quad \mathrm{NH}_{3}$ coeff., $3 \cdot 5 \%$. Acetone present; no diacetic acid.

Case 59.-Plasma : $\mathrm{NaCl}, 150 . \mathrm{HCO}_{3}, 73$. Protein, 16.5. P, 4. Urea, 4. Residue, 10.6. O.P., 258. Urine : pH. 7.2. $\mathrm{Cl}, 0$. Fixed base, 40 milliequivalents.

Case 63.-Plasma : $\mathrm{NaCl}, 184 . \mathrm{HCO}_{3}, 76 \cdot 5$. Residue, 40 at least. Minimum O.P., 300. Urine: pH. 6. Acidity, 62. $\mathrm{NH}_{3}, 34 . \mathrm{Cl}, 0 . \mathrm{P}_{2} \mathrm{O}_{5}, 50$.

Case 74.-Plasma : $\mathrm{NaCl}, 166 . \mathrm{HCO}_{3}, 68 . \quad$ Residue, 40 at least. Minimum O.P. 274. Urine : pH. 6.4. Acidity, 52. $\mathrm{NH}_{3}, 40 . \mathrm{Cl}, 0 . \mathrm{NH}_{3}$ coeff., 5.5. Fixed base, 128. Trace of acetone.

Case 75.-Plasma : $\mathrm{NaCl}, \mathrm{168} . \mathrm{HCO}_{3}, 69$. Urea, 12. Residue, 32 at least. Minimum O.P., 281. Urine : pH. 5.7. Acidity, 58. $\mathrm{NH}_{3}, 38 . \mathrm{Cl}, 0 . \mathrm{P}_{2} \mathrm{O}_{5}, 47 . \mathrm{SO}_{4}, 51 . \mathrm{NH}_{3}$ coeff., 4.5. Fixed base, 105. No acetone.

[NaCl-Sodium chloride; $\mathrm{HCO}_{3}$-bicarbonate; $\mathrm{NH}_{3}$-ammonia ; $\mathrm{P}_{2} \mathrm{O}_{5}$-phosphate ; $\mathrm{SO}_{4}$-sulphate.]

\section{REFERENCES.}

1. Hartmann, A. F., \& Smyth, F. S., Amer. J. Dis. Child., Chicago, 1926, XXXII, 1.

2. Graham, S., \& Morris, N., Arch. Dis. Childh., London, 1929, IV, 335.

3. Maizels, M., McArthur, C. B., \& Payne, W. W., Lancet, London, 1930, 286.

4. Hartmann, A. F., \& Darrow, D. C., J. Clin. Invest., Baltimore, 1928, VI, 127.

5. Maizels, M., \& McArthur, C. B., Quart. J. Med., Oxford, 1928-1929, XXII, 581.

6. Stadie, W. C., \& Ross, E. C., J. Biol. Chem., N.Y., 1925, XLV, 735.

7. Maizels, M., \& McArthur, C. B., Amer. J. Dis. Child., Chicago, 1930, XLI, 35. 